\title{
Prediksi Berat Badan Pasien Pediatri: Analisis Akurasi Mercy Method
}

\author{
Khildan Miftahul Firdaus, Arie Utariani \\ Departemen Anestesi dan Terapi Intensif \\ Fakultas Kedokteran Universitas Airlangga RSUD Dr Soetomo Surabaya
}

\begin{abstract}
Abstrak
Resusitasi pediatri bergantung pada berat badan untuk menentukan ukuran alat resusitasi, dosis obat, jumlah cairan, hingga dosis defibrilasi yang dibutuhkan. Berat badan aktual pada kondisi kegawatan sering kali sulit diukur sehingga membutuhkan suatu metode prediksi. Mercy method merupakan salah satu modalitas prediksi berat badan berbasis panjang yang dapat digunakan. Tujuan, menganalisis akurasi Mercy method sebagai metode prediksi berat badan pasien pediatri. Metode, dalam penelitian analitik observasional ini dilakukan pengukuran berat badan, panjang lengan, dan lingkar lengan atas tengah pada pasien usia 2 bulan-16 tahun di IRNA Pediatri RSUD Dr. Soetomo periode Desember 2019 hingga Maret 2020. Panjang dan lingkar lengan atas tengah kemudian dikonversi menjadi berat badan prediksi menggunakan Mercy method, lalu dilakukan uji korelasi dengan berat badan aktual. Uji bias dan predictive performance dinilai menggunakan ME, MAPE, RMSE, dan toleransi berat badan hingga 10\% dan 20\%. Hasil, dari 375 pasien, didapatkan hasil bahwa Mercy method merupakan modalitas yang baik untuk memprediksi berat badan pediatri pada populasi ini $(\mathrm{r} 2=.964 ; \mathrm{p}, 000)$. Hasil uji bias dan predictive performance juga menunjukkan hasil yang baik dengan ME yang rendah, MAPE $<10 \%$, RMSE mendekati nol, serta dapat memprediksi berat badan aktual dengan toleransi 20\% hingga 97,4\%. Simpulan, Mercy method merupakan metode yang akurat untuk memprediksi berat badan pasien pediatri di RSUD Dr. Soetomo Surabaya.
\end{abstract}

Kata kunci: Berat badan pediatri, Mercy method, prediksi berat badan pediatri

\section{Feasibility Analysis of the Mercy Method - Weight Estimation Pediatric Patients}

\begin{abstract}
Most pediatric resuscitations interventions are based on the patient's body weight to determine the resuscitation device's size, drug dose, amount of fluid needed, and defibrillation joule. Measurement of actual body weight in the emergency setting is often impossible because it requires a weight estimation method. The Mercy method is one of the modalities of length-based weight estimation used in emergency departments. Objective: to analyze Mercy method's accuracy as a weight estimation method in pediatric patients at RSUD Dr. Soetomo Surabaya in December 2019-March 2020. Methods: This prospective, observational analytic, single-center study, measured the actual body weight (ABW), humeral length (HL) and mid- arm circumference (MAC) of patients aged 2 months-16 years at the pediatric ward with consecutive sampling techniques. HL and MAC were converted to predictive body weight (PBW) based on Mercy method. Then, PBWs were regressed against ABWs. The predictive performance assessment used mean error (ME), mean absolute percentage error (MAPE), root mean square error (RMSE) and the predicted percentage was within 10\% and 20\% (Agreement 10\% and 20\%). Results from 375 pediatric patients showed that the Mercy method offered a good correlation between ABW and PBW (r2=.964, p.000); Mercy method also demonstrated good predictive performance results with low ME, MAPE $<10 \%$ and RMSE close to zero. The Mercy method estimated weight within 20\% of ABW for nearly all children $(97.4 \%)$ in this study population. In conclusion, the Mercy method performed exceptionally well in this study population without modification, extending this weight estimation strategy.
\end{abstract}

Keywords: Length-based weight estimation, Mercy method, pediatric weight

Korespondensi: Khildan Miftahul Firdaus, dr., Departemen Anestesi dan Terapi Intensif Fakultas Kedokteran Universitas Airlangga RSUD Dr. Soetomo Surabaya, Jl. Mayjen Prof. Dr. Moestopo No.6-8, Airlangga, Kec. Gubeng, Kota SBY, Jawa Timur 60286, Tlpn (031) 5501078, Email khildanmf@gmail.com 


\section{Pendahuluan}

Kegawatdaruratan pediatri merupakan salah satu hal yang sering dihadapi oleh seorang ahli anestesi di ruang resusitasi. Berdasar atas data di ruang gawat darurat pediatri di RSUD Dr Soetomo Surabaya didapatkan tren peningkatan jumlah pasien per tahunnya dari 1.575 pasien pada tahun 2018 menjadi 1.936 pasien pada tahun 2019 dan 29-33\% pasien tersebut masuk ke ruang resusitasi yang membutuhkan penanganan resusitasi segera. Seorang pasien pediatri dapat datang ke instalasi gawat darurat rumah sakit dengan kondisi klinis yang sangat bervariasi mulai dari yang paling ringan hingga paling berat. Kegawatdaruratan yang sering kali dilaporkan antara lain gagal napas, syok, kejang, dan atau disertai penurunan kesadaran, multitrauma. Keadaan tersebut membutuhkan penanganan resusitasi yang cepat dan tepat. ${ }^{1}$ Resusitasi pada pasien pediatri seperti pemilihan ukuran alat resusitasi, dosis obat, jumlah cairan infus hingga dosis kardioversi ataupun defibrilasi sangat bergantung pada berat badan pasien..$^{1-3}$

Kerap kali pasien pediatri datang diantar bukan oleh orangtuanya, atau orangtua tidak mengetahui berapa berat badan aktual pasien saat datang, sedangkan pasien tidak dalam kondisi yang memungkinkan untuk dilakukan pengukuran berat badan secara aktual. ${ }^{3,4}$ Ketidaktersediaan data berat badan ini menjadi masalah yang mendasar bagi seorang ahli anestesi untuk melakukan tindakan resusitasi secara tepat. Kesalahan dalam menetukan dosis obat, jumlah cairan infus, atau dalam mempersiapkan peralatan resusitasi yang sesuai dapat mengakibatkan masalah dan outcome yang tidak baik hingga dapat berakhir pada kematian., ${ }^{4,5}$

Selain menggunakan prediksi berat badan secara visual oleh orangtua ataupun tenaga medis yang akurasinya sangat bervariasi (55-71\%), ${ }^{6-9}$ dapat juga digunakan metode prediksi berat badan pasien berdasar atas usia dan atau panjang badan. Walaupun metode ini cukup sederhana dan mudah diintegrasikan ke dalam praktik klinis, metode prediksi berat badan berbasis usia tidak memperhitungkan perbedaan ekstrem komposisi tubuh dan tinggi badan pada anak dengan usia yang sama. Demikian pula, metode prediksi berat badan berbasis panjang badan (Broselow tape, Handtevy tape) tidak mempertimbangkan bahwa dua anak dengan tinggi yang sama dapat menunjukkan berat badan yang sangat berbeda berdasar atas status gizi yang mendasarinya (misal malnutrisi, berat badan kurang, berat badan lebih, obesitas). ${ }^{10-13}$

Mercy method merupakan metode prediksi berat badan yang menggabungkan panjang dan habitus tubuh sehingga dapat meningkatkan akurasi dari prediksi berat badan berdasar atas panjang dan menghilangkan subjektivitas untuk mengkategorikan tipe tubuh pasien pediatri. ${ }^{14,15}$ Mercy method menggunakan parameter panjang lengan dan lingkar lengan atas tengah (dalam $\mathrm{cm}$ ), kemudian dikonversi menjadi berat badan (dalam kg). Metode ini mampu memperkirakan berat pasien anak usia 2 bulan hingga 16 tahun dalam situasi dengan waktu yang terbatas. Kasus pasien pediatri tidak kooperatif (combative) atau tidak memungkinkan dilakukan pengukuran panjang badan dan atau tidak didapatkan data usia pasien..$^{10,15,16}$ Mercy method ataupun Mercy tape sudah banyak diteliti dan digunakan di negara lain, namun sepengetahuan penulis belum ada publikasi mengenai akurasi Mercy method pada populasi anak di Indonesia. Oleh karena itu, penelitian ini bertujuan menganalisis akurasi Mercy method pada populasi pasien pediatri di RSUD Dr. Soetomo Surabaya, Indonesia.

\section{Subjek dan Metode}

Penelitian ini merupakan metode penelitian prospektif, analitik observasional di RSUD Dr. Soetomo Surabaya yang dilaksanakan mulai bulan Desember 2019 hingga Maret 2020 yang telah mendapatkan persetujuan dari Komite Etik Rumah Sakit No.: 1751/ KEPK/X/2019. Subjek penelitian ini adalah semua pasien pediatri usia 2 bulan-16 tahun yang dirawat di Instalasi Rawat Inap Pediatri RSUD Dr. Soetomo Surabaya. Metode penelitian ini kemudian dijelaskan kepada 
orangtua/wali pasien, lalu bila bersedia menandatangani persetujuan atau informed consent maka pasien itu akan dimasukkan sebagai subjek penelitian. Pasien pediatri yang tidak kooperatif, memiliki kelainan kongenital yang menyebabkan deformitas panjang badan ataupun kelainan medis yang menyebabkan gangguan pada berat badan dan atau tinggi badan (amputasi, cerebral palsy, kontraktur sendi, malnutrisi, defisiensi hormon pertumbuhan, hidrocephalus), dan neonatus dikeluarkan dari penelitian ini. Teknik pengumpulan sampel menggunakan teknik concsecutive sampling bahwa semua sampel yang memenuhi kriteria inklusi dan tidak termasuk eksklusi dimasukkan dalam sampel penelitian hingga jumlah sampel minimal terpenuhi. Semua subjek penelitian mendapatkan perlakuan yang sama dan tidak dilakukan alokasi kelompok. Besar sampel penelitian dihitung menggunakan formula Lemeshow dengan interval kepercayaan 95\% dan $\mathrm{a}=0,05$ maka didapatkan besar sampel penelitian sejumlah 375 pasien.

Saat pengukuruan, variabel seperti usia, jenis kelamin, etnis, panjang badan, panjang lengan, lingkar lengan atas tengah, dan berat badan setiap anak dicatat pada lembar pengumpul data. Panjang badan didapat dengan stadiometer pada posisi berdiri atau menggunakan pita pengukur untuk anak kecil yang tidak mampu berdiri. Berat badan aktual diukur pada pasien dengan memakai gaun pasien menggunakan timbangan pengukur yang telah dikalibrasi sebelumnya. Panjang lengan dihitung melalui batas bawah akromion hingga batas atas olekranon dengan posisi tangan di samping pasien dan siku ditekuk 90 derajat. Lingkar lengan atas tengah diukur melalui batas tengah lengan, lalu diukur melingkar dengan posisi tangan menggantung. Panjang lengan dan lingkar lengan atas tengah (dalam $\mathrm{cm}$ ) kemudian dikonversi menjadi berat badan prediksi (dalam kg) menggunakan tabel konversi Mercy method.

Prediksi akurasi berat badan dinilai dengan meregresikan berat badan dengan interval kepercayaan 95\%, lalu dianalisis menggunakan uji korelasi. Persentase antara berat badan estimasi dan berat badan aktual ditentukan secara visual dengan plot. Mean error (ME) dikalkulasikan dengan menilai perbedaan berat badan aktual dan prediksi lalu direratakan. Mean absolute percentage error (MAPE) diukur dengan membagi mean error dengan berat badan aktual lalu dikalikan 100 . Root mean square error (RMSE) dikalkulasikan dengan mengakarkan rerata squared error. Agreement 10\% dan 20\% adalah berat badan prediksi yang dianggap benar dengan toleransi $10 \%$ dan 20\% dari berat badan aktual. Analisis statistik dikerjakan dengan statistical product and servise solution (SPSS) v19.

\section{Hasil}

Penelitian melibatkan 375 pasien pediatri dengan distribusi antara laki-laki dan perempuan sebesar $50,4 \%$ berbanding $49,6 \%$ dengan sebaran dari populasi penelitian berdasar atas kelompok usia dan status gizi (Tabel 2).

Status gizi dinilai menggunakan kurva pertumbuhan indeks massa tubuh (IMT) sesuai dengan usia dari WHO. Bila titik perpotongan antara IMT dan usia berada antara garis $z$-score -2 hingga 2 maka pasien dikategorikan sebagai status gizi normal. Status gizi kurang (kurus/sangat kurus) didefinisikan bila titik perpotongan tersebut berada di bawah garis z-score -2 dan status gizi lebih (overweight/ obesitas) bila titik perpotongan tersebut berada di atas garis $z$-score 2 .

Jumlah subjek penelitian tiap-tiap jenjang usia memiliki rentang 18-38 pasien dengan rerata $22,06 \pm 5,13$ pasien.

Karakteristik subjek penelitian yang meliputi rentang minimal, maksimal, serta rerata parameter panjang badan, panjang lengan, diameter lingkar lengan atas tengah, berat badan aktual, berat badan prediksi, serta selisih berat badan dipaparkan pada Tabel 3 . Selisih berat badan merupakan selisih antara berat badan prediksi dikurangi berat badan aktual. Hasil positif menandakan bahwa berat badan aktual lebih kecil daripada berat badan prediksi yang berarti bahwa Mercy Method ini overestimate dan berlaku juga sebaliknya. Dari 
Tabel 1 Tabel Konversi Mercy Method

\begin{tabular}{|c|c|c|c|}
\hline $\begin{array}{l}\text { Panjang Lengan } \\
\text { (cm) }\end{array}$ & $\begin{array}{c}\text { Fraksi Pertama } \\
\text { Berat Badan } \\
\text { (kg) }\end{array}$ & $\begin{array}{c}\text { Lingkar Lengan } \\
\text { Atas Tengah } \\
\text { (cm) }\end{array}$ & $\begin{array}{c}\text { Fraksi Kedua } \\
\text { Berat Badan } \\
\text { (kg) }\end{array}$ \\
\hline 9 & 0,5 & 10 & 2,8 \\
\hline 10 & 0,7 & 11 & 3,8 \\
\hline 11 & 0,9 & 12 & 4,6 \\
\hline 12 & 1,5 & 13 & 4,9 \\
\hline 13 & 2,0 & 14 & 5,3 \\
\hline 14 & 2,8 & 15 & 5,9 \\
\hline 15 & 3,4 & 16 & 6,5 \\
\hline 16 & 4,2 & 17 & 7,4 \\
\hline 17 & 5,0 & 18 & 8,0 \\
\hline 18 & 6,1 & 19 & 9,4 \\
\hline 19 & 7,2 & 20 & 10,9 \\
\hline 20 & 8,1 & 21 & 12,4 \\
\hline 21 & 9,1 & 22 & 14,3 \\
\hline 22 & 10,4 & 23 & 16,5 \\
\hline 23 & 11,4 & 24 & 18,0 \\
\hline 24 & 12,6 & 25 & 20,5 \\
\hline 25 & 13,7 & 26 & 23,4 \\
\hline 26 & 14,7 & 27 & 25,5 \\
\hline 27 & 16,6 & 28 & 27,8 \\
\hline 28 & 18,3 & 29 & 30,5 \\
\hline 29 & 19,6 & 30 & 33,3 \\
\hline 30 & 21,4 & 31 & 36,3 \\
\hline 31 & 23,7 & 32 & 39,6 \\
\hline 32 & 25,5 & 33 & 44,8 \\
\hline 33 & 27,3 & 34 & 46,5 \\
\hline 34 & 29,2 & 35 & 50,2 \\
\hline 35 & 31,0 & 36 & 53,2 \\
\hline 36 & 33,5 & 37 & 55,7 \\
\hline 37 & 34,5 & 38 & 60,3 \\
\hline 38 & 36,5 & 39 & 61,1 \\
\hline 39 & 38,2 & 40 & 67,0 \\
\hline
\end{tabular}

Sumber: Abdel-Rahman dan Ridge ${ }^{16}$

hasil rerata selisih berat badan didapatkan 0,19 kg dengan kecenderungan overestimate.

Mercy method menggambarkan korelasi yang baik panjang lengan dan lingkar lengan atas tengah dengan berat badan aktual $\left(r^{2}\right.$ $=0,964: p, 000)$. Pada penelitian ini Mercy method menghasilkan bias hasil yang minimal, hal ini tergambar dari hasil mean error (ME) yang kecil, yaitu 0,19 kg (2,05). Mean absolute percentage error (MAPE) -0,57\% $(8,35)$ menggambarkan persentase kesalahan hasil prediksi terhadap berat badan aktual. Root mean squared error (RMSE) merupakan salah satu cara untuk mengevaluasi model 
Tabel 2 Demografi Antropometrik Subjek Penelitian

\begin{tabular}{lcc}
\hline \multicolumn{1}{c}{ Data Demografi } & $\mathbf{n = 3 7 5}$ & Persentase \\
\hline $\begin{array}{l}\text { Jenis kelamin } \\
\text { Laki-laki }\end{array}$ & 189 & 50,4 \\
$\quad$ Perempuan & 186 & 49,6 \\
$\quad$ Kelompok usia & & \\
$\quad$ Infant (2 bulan- & 38 & 10,1 \\
1 tahun) & & \\
$\quad$ Anak usia 2-9 tahun & 205 & 54,7 \\
$\quad$ Anak usia 10-16 tahun & 132 & 35,2 \\
Status gizi & & \\
$\quad$ Gizi kurang & 93 & 24,8 \\
$\quad$ Normal & 272 & 72,5 \\
$\quad$ Gizi lebih & 10 & 2,7 \\
\hline
\end{tabular}

regresi linear dengan mengukur tingkat akurasi hasil perkiraan suatu model. Bila hasilnya semakin mendekati nol maka tingkat akurasinya semakin baik dan pada penelitian ini didapatkan hasil RSME 2,06. Kemudian, dilakukan uji dengan toleransi berat badan $10 \%$ dari berat badan aktual, Mercy method mampu memprediksi dengan benar dalam batas toleransi berat badan pada $76,5 \%$ dari populasi dan bila toleransi dinaikkan hingga $20 \%$, metode ini mampu memprediksi dengan benar berat badan hampir seluruh populasi penelitian (97,3\%). Setelah dilakukan olah data dengan membagi populasi berdasar atas kategori jenis kelamin, kelompok usia, dan status gizi didapatkan hasil yang bervariasi dengan koefisien regresi 0,784-0,931 (Tabel 4). Pada subgrup jenis kelamin laki-laki dan perempuan didapatkan hasil yang hampir serupa dengan nilai koefisien regresi 0,919 dibanding 0,927 serta uji bias dan presisi yang

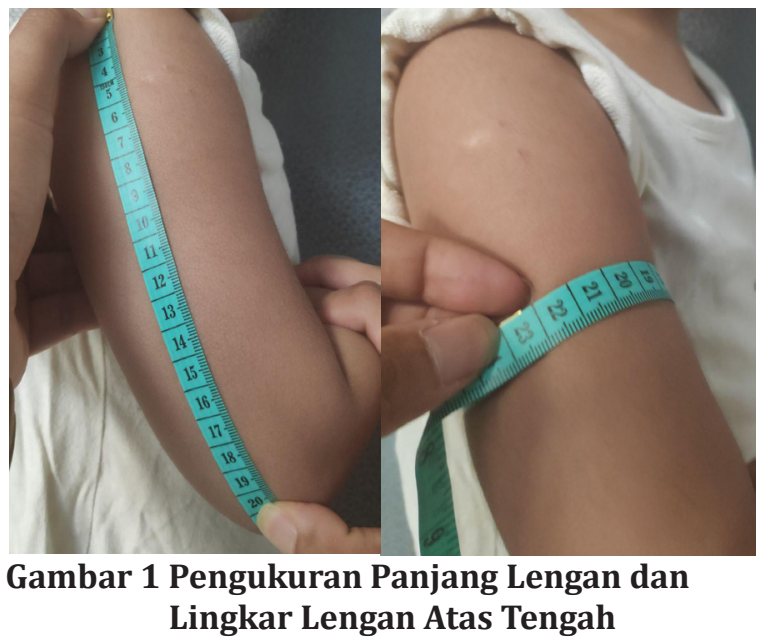

mirip. Pada subgrup infant, pediatri, dan anak usia 10-16 tahun didapatkan korelasi yang tidak jauh berbeda dengan kooefisien regresi 0,916 dibanding 0,910 dan 0,894 dengan uji bias dan presisi yang lebih baik pada grup infant. Pada subgrup gizi kurang, normal, dan gizi lebih dihasilkan korelasi yang bervariasi dengan koefisien regresi 0,872 berbanding 0,931 dan 0,784 dengan uji bias dan presisi yang lebih baik pada subgrup gizi normal.

\section{Pembahasan}

Pengukuran berat badan pada pediatri dengan penyakit kritis menjadi kesulitan tersendiri bagi seorang ahli anestesi yang bertugas di ruang resusitasi dan perawatan intensif. ${ }^{2} \mathrm{Hal}$ ini terkait dengan keterbatasan mobilisasi pasien serta kondisi dan tingkat kesadaran yang bervariasi. Umumnya dilaksanakan pengukuran berat badan secara aktual pada

Tabel 3 Karakteristik Subjek Penelitian

\begin{tabular}{lccc}
\hline Karakteristik (n=375) & Means (SD) & Minimal & Maksimal \\
\hline Panjang badan/PB (cm) & $110,75(28,9)$ & 52,00 & 168,00 \\
Panjang lengan/PL (cm) & $23,05(6,31)$ & 7,50 & 38,00 \\
Lingkar lengan atas tengah/LL (cm) & $17,70(5,20)$ & 8,00 & 33,00 \\
Berat badan aktual/BBA (kg) & $23,54(14,50)$ & 3,50 & 72,00 \\
Berat badan prediksi/BBP (kg) & $23,35(14,54)$ & 3,60 & 72,80 \\
Selisih berat badan=BBP-BBA/DBB(kg) & $0,19(2,05)$ & 9,50 & $-7,00$ \\
& & (Overestimate) & (Underestimate) \\
\hline
\end{tabular}

Keterangan: data didapatkan dari uji deskriptif 
Tabel 4 Parameter Regresi dan Kinerja Prediksi dari Mercy Method berdasar atas Kategori

\begin{tabular}{|c|c|c|c|c|c|c|c|c|c|}
\hline & \multirow{2}{*}{$\mathbf{n}$} & \multirow{2}{*}{$\mathbf{r}^{2}$} & \multirow{2}{*}{ ME (kg) } & \multirow{2}{*}{ MAPE (\%) } & \multirow{2}{*}{ RMSE } & \multicolumn{2}{|c|}{ \%Agreement } & \multirow{2}{*}{$\mathbf{p}^{*}$} \\
\hline & & & & & & & $10 \%$ & $20 \%$ & \\
\hline \multicolumn{2}{|c|}{ Mercy Method } & 375 & 0,964 & $-0,19(2,05)$ & $0,57(8,35)$ & 2,06 & 76,5 & 97,3 & , 000 \\
\hline \multirow{3}{*}{$\begin{array}{l}\text { Jenis } \\
\text { kelamin }\end{array}$} & Laki-Laki & 189 & 0,919 & $-0,21(2,01)$ & $0,92(8,87)$ & 2,10 & 73,0 & 97,4 & 000 \\
\hline & Perempuan & 186 & 0,927 & $-0,16(2,00)$ & $0,22(7,77)$ & 2,01 & 80,1 & 97,3 & ,000 \\
\hline & Infant & 38 & 0,916 & $-0,04(, 26)$ & $0,18(4,31)$ & 0,26 & 97,4 & 100 & ,000 \\
\hline \multirow[t]{3}{*}{$\begin{array}{l}\text { Kelompok } \\
\text { usia }\end{array}$} & $\begin{array}{l}\text { Anak usia } \\
2-9 \text { tahun }\end{array}$ & 205 & 0,910 & $-0,16(1,54)$ & $0,82(8,60)$ & 1,54 & 74,6 & 97,1 & ,000 \\
\hline & $\begin{array}{l}\text { Anak usia } \\
10-16 \text { tahun }\end{array}$ & 132 & 0,894 & $-0,27(2,88)$ & $0,40(8,80)$ & 2,88 & 73,5 & 97,0 & ,000 \\
\hline & Gizi kurang & 93 & 0,929 & $0,62(1,76)$ & $4,47(9,47)$ & 1,86 & 59,1 & 94,6 & ,000 \\
\hline \multirow[t]{2}{*}{ Status gizi } & Normal & 272 & 0,931 & $-0,42(2,02)$ & $0,64(7,50)$ & 2,06 & 82,7 & 98,2 & 000 \\
\hline & Gizi lebih & 10 & 0,784 & $-1,32(3,20)$ & $2,86(7,53)$ & 3,31 & 70,0 & 100 & 001 \\
\hline
\end{tabular}

Keterangan: *nilai p didapatkan dari hasil uji Pearson, signifikan jika $\mathrm{p}<0,05$

ME (mean error), MAPE (mean absolute percentage error), RMSE (root mean square error)

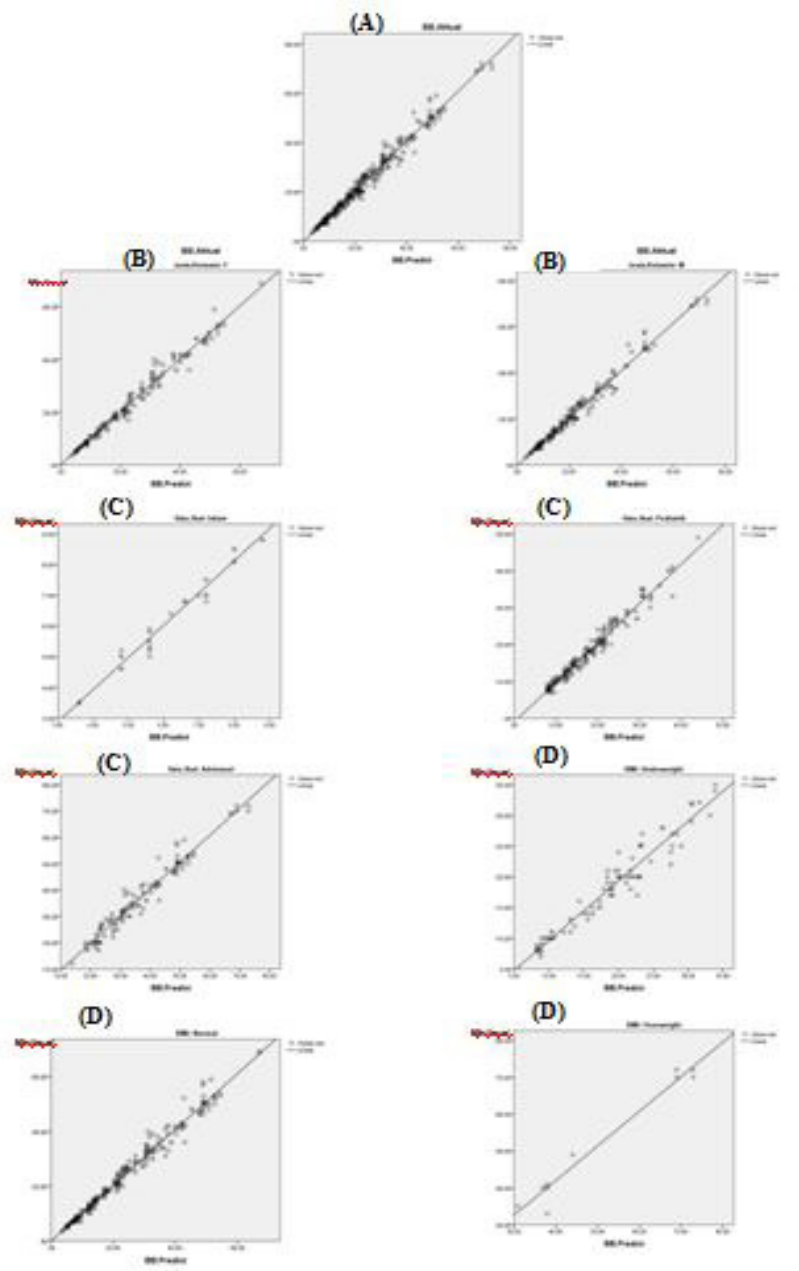

Gambar 2 Korelasi Berat Badan Prediksi dengan Berat Badan Aktual (A) dan berdasar atas Kategori Jenis Kelamin (B), Usia (C), dan Status Gizi (D) 
posisi tidur terlentang (untuk infant) ataupun posisi berdiri pada pasien pediatri yang lebih besar menggunakan timbangan berat badan. Namun, akibat keterbatasan untuk melakukan pengukuran berat badan secara aktual pada kondisi gawat darurat dan mengancam nyawa, dibutuhkan suatu metode pengganti untuk mengukur berat badan pada pasien tersebut yang antara lain dengan mengukur panjang lengan dan lingkar lengan atas tengah. ${ }^{5}$

Mercy method tersebutmempertimbangkan kecepatan pertumbuhan pasien pediatri mempergunakan panjang humerus sebagai pengganti panjang tubuh total. Membatasi pengukuran panjang pada satu tulang panjang meminimalkan perbedaan yang diperoleh dari hasil pengukuran panjang pasien pediatri pada posisi berdiri ataupun tidur telentang dan mungkin lebih mudah serta lebih cepat dilakukan pengukuran daripada harus mengukur panjang badan total pada pasien yang tidak kooperatif. Mercy method juga memasukkan habitus sebagai variabel yang dapat meningkatkan akurasi dari prediksi berat badan berdasar atas panjang badan dan menghilangkan subjektivitas untuk mengkategorikan tipe tubuh pasien pediatri. Metode ini diharapkan mampu mengurangi limitasi yang biasanya diakibatkan oleh peningkatan berat badan yang tidak proporsional dibanding dengan panjang badan pada pasien pediatri yang lebih besar. Metode lain yang dirancang dengan tulang panjang yang berbeda (misal ulna, tibia) dan prediksi habitus yang lain (misal lingkar paha, lingkar perut) mungkin dapat digunakan, namun harus dikaji lebih lanjut dan harus menunjukkan akurasi yang sebanding dengan Mercy method. ${ }^{14,15}$

Penelitian ini melibatkan 375 pasien dengan rentang usia 2 bulan hingga 16 tahun yang dirawat di IRNA Pediatri RSUD Dr. Soetomo dengan jumlah populasi lakilaki sedikit lebih banyak dibanding dengan perempuan $(50,4 \%$ vs $49,6 \%)$ dan rerata usia 7,2 tahun, median 7 tahun (SD $\pm 4,97)$. Karakteristik pasien berdasar atas indeks massa tubuh sedikit berbeda bila dibanding dengan beberapa penelitian sebelumnya. Pada penelitian sebelumnya di Amerika Serikat ataupun Australia didapatkan karakteristik anak dengan gizi lebih ternyata lebih banyak daripada anak gizi kurang. ${ }^{16-18}$ Pada penelitian ini didapatkan jumlah subjek status gizi kurang yang lebih banyak dibanding dengan gizi lebih. Karakteristik subjek penelitian ini lebih mirip dengan populasi di India dan Afrika. ${ }^{14,19,20}$ Tidak ada pasien yang drop-out.

Pada penelitian ini didapatkan hasil yang serupa dengan penelitian sebelumnya dengan nilai $r^{2} 0,964(\mathrm{p}=0,000)$ bahwa panjang lengan dan dan lingkar lengan atas (Mercy method) memiliki hubungan korelasi yang kuat dengan berat badan pasien pediatri.

Pada subgrup laki-laki dan perempuan, hubungan antara panjang lengan dan lingkar lengan atas tengah dinyatakan dengan koefisien regresi 0,919 berbanding 0,927. Pada uji bias dan presisi, subgrup perempuan sedikit lebih unggul daripada subgrup lakilaki dengan hasil MAPE yang lebih rendah dan Agreement 10\% yang sedikit lebih tinggi. Hasil penelitian ini tidak berbeda bila dibanding dengan seluruh penelitian sebelumnya yang menghasilkan simpulan bahwa hanya ada sedikit variasi dalam akurasi Mercy method untuk memprediksi berat badan pada pasien pediatrilaki-lakiataupun perempuan. . $3,14,16,18-20$

Ketika distratifikasi berdasar atas kategori usia, uji korelasi menunjukkan hasil yang tidak terlalu berbeda $(0,916 ; 0,91 ; 0,894$ berturutturut). Uji bias dan presisi pada subgrup infant mendapatkan hasil yang sangat baik (ME -0,037 kg; MAPE 0,18\%; RMSE 0,26; Agreement 10\% 97,4\%). Hal ini menggambarkan bahwa Mercy method baik digunakan pada semua pasien pediatri di seluruh rentang usia. ${ }^{15,20,21}$

Pada hasil pengelompokan berdasar atas status gizi didapatkan hasil yang mendukung penelitian sebelumnya. Mercy method ini ketika dilakukan uji bias dan presisi didapatkan hasil yang sedikit lebih inferior pada subgrup gizi kurang dibanding dengan subgrup status gizi normal ataupun gizi lebih. Pada subgrup gizi kurang didapatkan MAPE yang lebih tinggi $(4,47 \%)$ dan Agreement 10\% yang lebih rendah $(59,1 \%)$ dibanding dengan kedua subgrup lainnya. ${ }^{14,16,19,20}$ 
Hal ini menggambarkan bahwa walaupun berdasar atas uji korelasi ketiga subgrup BMI memiliki koefisien regresi yang sama baiknya, diperlukan kehati-hatian penggunaannya pada pasien pediatri dengan status gizi kurang. Pada subgrup ini juga didapatkan sedikit perbedaan dibanding dengan subgrup lainnya. Pada subgrup gizi kurang didapatkan hasil cenderung underestimate dibanding dengan berat badan aktual pasien pediatri. Sebaliknya, pada subgrup gizi lebih didapatkan hasil yang relatif overestimate dengan ME yang lebih besar dibanding dengan subgrup lainnya $(1,32 \mathrm{~kg}$; SD 3,20). Pada subgrup gizi lebih didapatkan hasil yang berbeda dengan penelitian dari Wells tahun 2020. Dari penelitian dari Wells $\mathrm{dkk}^{22}$ pada 1.318 pasien pediatri gizi lebih mendapatkan hasil bahwa Mercy method ini sangat baik dan tidak memerlukan modifikasi pada pasien obesitas. Pada penelitian ini belum dapat disimpulkan apakah performa Mercy method pada subgrup gizi lebih memang lebih inferior dibanding dengan subgrup lain karena jumlah subjek penelitian ini lebih sedikit. Bila dilakukan penambahan jumlah sampel hingga mendekati kedua subgrup lain, mungkin akan didapatkan hasil yang berbeda.

Berdasar atas hasil penelitian ini maka metode ini sangat baik sebagai alat bantu prediksi berat badan pada pasien pediatri dan tidak memerlukan modifikasi dalam penggunaannya. Prediksi berat badan pada pasien perempuan tidak terlalu berbeda dibanding dengan pasien laki-laki. Pada infant, metode ini mampu memprediksi berat badan dengan sangat baik dan presisi yang mendekati berat badan aktual. Berat badan dengan BMI normal masih sedikit lebih unggul dibanding dengan dua subgrup lainnya, namun dengan tingkat akurasi yang tidak terlalu berbeda.

Kelemahan penelitian ini adalah singlecenter study dan hanya menyertakan pasien pediatri di rawat inap dengan kondisi yang relatif sehat atau sakit kronis, sedangkan pada pasien sakit kritis dengan kegawatdaruratan akut mungkin didapatkan perbedaan habitus tubuh ataupun berat badan. Penelitian ini hanya melibatkan satu orang pengukur untuk melakukan pengukuran sehingga tidak didapatkan perbandingan pengukuran.

\section{Simpulan}

Pengukuran panjang lengan dan lingkar lengan atas tengah berdasar atas Mercy method merupakan alat bantu yang akurat memprediksi berat badan pada populasi pasien pediatri.

\section{Daftar Pustaka}

1. AlSulaibikh, AH, Al-Ojyan FI, Al-Mulhim, KN, Alotaibi TS, Alqurashi FO, Almoaibed LF, dkk. The accuracy of broselow pediatric emergency tape in estimating body weight of pediatric patients. Saudi Med J. 2017;38(8):798-803.

2. Mishra DG, Kole T, Nagpal R, Smith JP. A correlation analysis of Broselow ${ }^{\mathrm{TM}}$ Pediatric emergency tape-determined pediatric weight with actual pediatric weight in India. World J Emerg Med. 2016;7(1):40-3.

3. Asskaryar F, Shankar R. An Indian pediatric emergency weight estimation tool: prospective adjustment of the Broselow tape. Int J Emerg Med. 2015;8(1):78.

4. Shah AN, Frush K, Luo X, Wears RL. Effect of an intervention standardization system on pediatric dosing and equipment size determination: a crossover trial involving simulated resuscitation events. Arch Pediatr Adolesc Med. 2003;157(3):22936.

5. Larose G, Levy A, Bailey B, CumminsMcManus B, Lebel D, Gravel J. Decreasing prescribing errors during pediatric emergencies: a randomized simulation trial. Pediatrics. 2017;139(3):e20163200.

6. Lesar T, Lomaestro B, Pohl H. Medicationprescribing error in teaching hospital: a 9 year experience. Arch Intern Med. 1997;157(14):1569-76.

7. Harris M, Patterson J, Morse J. Doctors, nurses, and parents are equally poor at estimating pediatric weight. Pediatr Emerg Care. 1999;15(1):17-8.

8. Krieser D, Nguyen K, Kerr D, Jolley D, Clooney M, Kelly A. Parental weight 
estimation of their child's weight is more accurate than other weight estimation methods for determining children's weight in an emergency department?. Emerg Med J. 2007;24(11):756-9.

9. Partridge RL, Abramo TJ, Haggarty KA, Hearn R, Sutton KL, An AQ, dkk. Analysis of parental and nurse weight estimates of children in the pediatric emergency department. Pediatr Emerg Care. 2009;25(12):816-8.

10. Wells M, Goldstein L, Bentley A. Accuracy of weight estimation by the Broselow tape is substantially improved by including a visual assessment of body habitus. Pediatr Res. 2018;83(1-1):83-92.

11. Luten R, Zaritsky A. The sophistication of simplicity optimizing emergency dosing. Acad Emerg Med. 2008;15(5):461-5.

12. Kindig M, DeBoer S, Seaver M, deoboer L, Bacon J. A tale of two tapes: BroselowLuten tapes, 2011 vs 2017. JEMS [Online journal] 2019 [diunduh 12 Maret 2020]. Tersedia dari: https://www.jems. com/2019/04/29/a-tale-of-two-tapesbroselow-luten-tapes-2011-vs-2017/.

13. Wells M, Coovadia A, Kramer E. The PAWPER tape: a new concept tape-based device that increases the accuracy of weight estimation in children through the inclusion of a modifier based on body habitus. Resuscitation. 2013;84(2):22732.

14. Batmanabane G, Jena PK, Dikshit R, Abdel-Rahman $\mathrm{S}$. Using the mercy method for weight estimation in Indian children. Glob Pediatr Health. 2015;2:1-7. doi:10.1177/2333794X14566625.

15. Abdel-Rahman SM, Paul IM, James LP, Lewandowski A. Evaluation of the Mercy
TAPE: performance against the standard for pediatric weight estimation. Ann Emerg Med. 2013;62(4):332-9.e6.

16. Abdel-Rahman SM, Ridge AL. An improved pediatric weight estimation strategy. Open Med Devices J. 2012;4:87-97.

17. Wells M, Goldstein LN, Bentley A. The accuracy of paediatric weight estimation during simulated emergencies: the effects of patient position, patient cooperation, and human errors. African J Emerg Med. 2018;8(2):43-50.

18. O'Leary F, John-Denny B, McGarvey K, Hann A, Pegiazoglou I, Peat J. Estimating the weight of ethnically diverse children attending an Australian emergency department: a prospective, blinded, comparison of age-based and lengthbased tools including Mercy, PAWPER and Broselow. Arch Dis Child. 2017;102(1):4652.

19. Georgoulas VG, Wells M. The PAWPER tape and the Mercy method outperform other methods of weight estimation in children at a public hospital in South Africa. S Afr Med J. 2016;106(9):933-9.

20. Dicko A, Alhousseini MA, Sidibé B, Traoré M, Abdel-Rahman SM. Evaluation of the Mercy weight estimation method in Ouelessebougou, Mali. BMC Public Health. 2014;14:270.

21. Wells M, Goldstein L. Are "virtual" paediatric weight estimation studies valid?. Afr J Emerg Med. 2019;9(1):36-40.

22. Wells M, Goldstein L. Using the Mercy method to estimate ideal body weight in children: a description and validation of a new methodology. Cureus. 2020;12 (5):e8232. 